\title{
Fish predation hinders the success of coral restoration efforts using fragmented massive corals
}

\author{
Gammon Koval ${ }^{\text {Corresp., } 1}$, Nicolas Rivas ${ }^{1}$, Martine D'Alessandro ${ }^{1}$, Dalton Hesley ${ }^{1}$, Rolando Santos ${ }^{2}$, Diego Lirman ${ }^{1}$ \\ ${ }^{1}$ Rosenstiel School of Marine and Atmospheric Science, University of Miami, Miami, Florida, United States \\ 2 Department of Earth and Environment, Florida International University, Miami, Florida, United States \\ Corresponding Author: Gammon Koval \\ Email address: gnk2@miami.edu
}

As coral reefs continue to decline globally, coral restoration practitioners have explored various approaches to return coral cover and diversity to decimated reefs. While branching coral species have long been the focus of restoration efforts, the recent development of the microfragmentation coral propagation technique has made it possible to incorporate massive coral species into restoration efforts. Microfragmentation (i.e., the process of cutting large donor colonies into small fragments that grow fast) has yielded promising early results. Still, best practices for outplanting fragmented corals of massive morphologies are continuing to be developed and modified to maximize survivorship. Here, we compared outplant success among four species of massive corals (Orbicella faveolata, Montastraea cavernosa, Pseudodiploria clivosa, and P. strigosa) in Southeast Florida, US. Within the first week following coral deployment, predation impacts by fish on the small $\left(<5 \mathrm{~cm}^{2}\right)$ outplanted colonies resulted in both the complete removal of colonies and significant tissue damage, as evidenced by bite marks. In our study, 8-27\% of fragments from four species were removed by fish within one week, with removal rates slowing down over time. Of the corals that remained after one week, over $9 \%$ showed signs of fish predation. Our findings showed that predation by corallivorous fish taxa like butterflyfishes (Chaetodontidae), parrotfishes (Scaridae), and damselfishes (Pomacentridae) is a major threat to coral outplants, and that susceptibility varied significantly among coral species and outplanting method. Moreover, we identify factors that reduce predation impacts such as: 1 ) using cement instead of glue to attach corals, 2) elevating fragments off the substrate, and 3) limiting the amount of skeleton exposed at the time of outplanting. These strategies are essential to maximizing the efficiency of outplanting techniques and enhancing the impact of reef restoration. 
1 Fish predation hinders the success of coral

2 restoration efforts using fragmented massive corals

3

4

5

6 10

\author{
Gammon Koval ${ }^{1}$, Nicolas Rivas ${ }^{1}$, Martine D’Alessandro ${ }^{1}$, Dalton Hesley ${ }^{1}$, Rolando Santos ${ }^{2}$, \\ Diego Lirman ${ }^{1}$ \\ ${ }^{1}$ Rosenstiel School of Marine and Atmospheric Science, University of Miami, Miami, Florida, \\ USA \\ ${ }^{2}$ Department of Earth and Environment, Florida International University, Miami, Florida, USA
}

Corresponding Author:

Gammon Koval ${ }^{1}$

4600 Rickenbacker Causeway, Miami, Florida, 33149, USA

Email address: gnk2@miami.edu

\title{
Abstract
}

As coral reefs continue to decline globally, coral restoration practitioners have explored various approaches to return coral cover and diversity to decimated reefs. While branching coral species have long been the focus of restoration efforts, the recent development of the microfragmentation coral propagation technique has made it possible to incorporate massive coral species into restoration efforts. Microfragmentation (i.e., the process of cutting large donor colonies into small fragments that grow fast) has yielded promising early results. Still, best practices for outplanting fragmented corals of massive morphologies are continuing to be developed and modified to maximize survivorship. Here, we compared outplant success among four species of massive corals (Orbicella faveolata, Montastraea cavernosa, Pseudodiploria clivosa, and $P$. strigosa) in Southeast Florida, US. Within the first week following coral deployment, predation impacts by fish on the small $\left(<5 \mathrm{~cm}^{2}\right)$ outplanted colonies resulted in both the complete removal of colonies and significant tissue damage, as evidenced by bite marks. In our study, $8-27 \%$ of fragments from four species were removed by fish within one week, with removal rates slowing down over time. Of the corals that remained after one week, over $9 \%$ showed signs of fish predation. Our findings showed that predation by corallivorous fish taxa like butterflyfishes (Chaetodontidae), parrotfishes (Scaridae), and damselfishes (Pomacentridae) is a major threat to coral outplants, and that susceptibility varied significantly among coral species and outplanting method. Moreover, we identify factors that reduce predation impacts such as: 1) using cement instead of glue to attach corals, 2) elevating fragments off the substrate, and 3) limiting the amount of skeleton exposed at the time of outplanting. These strategies are essential to maximizing the efficiency of outplanting techniques and enhancing the impact of reef restoration. 


\section{Introduction}

41 Coral populations have experienced drastic declines due to a variety of stressors (Gardner et al.

42 2003; McLean et al. 2016). Globally, increases in ocean temperature and ocean acidification are

43 the most serious threats and can lead to mass coral mortality and reduced calcification rates

44 (Hoey et al. 2016). Rising ocean temperatures have resulted in increased frequency and intensity

45 of bleaching events (Heron et al. 2016; Hughes et al. 2019). Also, ocean acidification has begun

46 to reduce coral calcification rates and cause framework erosion (Muehllehner et al. 2016). The

47 magnitude and rate of coral decline require drastic, large scale actions to curb climate change

48 impacts as well as a suite of local conservation and management measures. Active coral reef

49 restoration has developed as one of the tools available to foster coral recovery and restore the

50 ecosystem services that healthy coral reefs provide (Rinkevich 2019). The present study focused

51 on South Florida reefs where coral abundance has declined due to the interaction of high and low

52 thermal anomalies (Lirman et al. 2010; Manzello 2015; Drury et al. 2017), nutrient inputs and

53 algal overgrowth (Lapointe et al. 2019), hurricanes (Lirman and Fong 1997), sedimentation

54 (Cunning et al. 2019), and coral diseases (Richardson et al. 1998; Precht et al. 2016; Walton et

55 al. 2018).

A popular method of coral reef restoration is coral gardening, where coral stocks propagated through sequential fragmentation within in-water and ex situ nurseries are outplanted in large numbers onto depleted reefs (Rinkevich 2006). Until recently, restoration programs based on the coral gardening methodology have focused primarily on branching taxa like Acropora due to their rapid growth rates, resilience to fragmentation, pruning vigor, and ease of outplanting (Bowden-Kerby 2008; Shaish et al. 2010; Lirman et al. 2014; Schopmeyer et al. 2017). While acroporids rapidly enhance the structural complexity of reefs, focusing restoration efforts on single taxa ignores the role that diversity plays in ecosystem function (Brandl et al. 2019) and makes restored communities susceptible to disturbances like diseases or storms that affect branching corals disproportionately. Thus, there is a need to expand our restoration toolbox to include multiple species with different morphologies and life histories (Lustic et al. 2020). The use of massive corals for restoration was initially hindered by the slow growth rates associated with these taxa. However, recent developments in microfragmentation and reskinning techniques (Forsman et al. 2015) that accelerate the growth of massive corals have made it possible to use these reefbuilding taxa for restoration.

The microfragmentation process involves fragmenting corals with massive morphologies into small $\left(<5 \mathrm{~cm}^{2}\right)$ ramets that consist mostly of living tissue and a limited amount of skeleton (Page et al. 2018). These microfragments can be mounted onto various types of substrate (e.g., ceramic plugs, plastic cards, cement pucks) using glue or epoxy and allowed to grow by skirting over the attachment platform before being outplanted. Once fragmented, ramets of Pseudodiploria clivosa and Orbicella faveolata grew up to $48 \mathrm{~cm}^{2}$ and $63 \mathrm{~cm}^{2}$ per month, respectively (Forsman et al. 2015) and were thereby capable of achieving colony sizes within a few months that would otherwise take years to develop after natural recruitment. Moreover, a single parent colony can produce hundreds of ramets available for continued propagation and restoration.

The microfragmentation technique overcomes the slow-growth bottleneck, but methods for 
82 maximize outplant survivorship and success. This is especially relevant in Florida and the

83 Caribbean where the massive coral species used here have been severely impacted by the recent 84 outbreak of stony coral tissue loss disease (SCTLD) (Precht et al. 2016; Alvarez-Filip et al. 2019).

85 The present study is one of the first to record the survivorship of small fragments of four species 86 of massive corals (O. faveolata, Montastraea cavernosa, P. clivosa, and P. strigosa) outplanted 87 onto reefs in Southeast Florida, US. To measure the success of this technique, we: 1) documented 88 survivorship and removal probability of fragments outplanted using different techniques, 2) 89 monitored the impacts of fish predation on newly planted fragments, and 3) evaluated different 90 outplanting techniques that may reduce the impacts of predation (i.e. coral fragment removal and 91 mortality).

92

\section{Materials \& Methods}

\section{Coral Fragmentation}

Colonies used in both experiments were collected from a seawall at Fisher Island, Miami, Florida $\left(25.76^{\circ} \mathrm{N}, 80.14^{\circ} \mathrm{W}\right.$; depth $\left.=1.8 \mathrm{~m}\right)$. Each parent colony was cut into small fragments (average size $=4.2 \pm 1.9 \mathrm{~cm}^{2}$ (mean $\pm \mathrm{SD}$ ) using a diamond band saw, and fragments were attached to ceramic plugs using super glue as described by Page et al. (2018). After fragmentation, the height of the fragments ranged from $0.5-1.0 \mathrm{~cm}$. The ceramic plugs with corals were placed on PVC frames and then fixed to coral trees (Nedimyer et al. 2011) at the University of Miami's in-water coral nursery $\left(25.69^{\circ} \mathrm{N}, 80.09^{\circ} \mathrm{W}\right.$; depth $\left.=9.4 \mathrm{~m}\right)$ where they were allowed to acclimate for 4-6 weeks before outplanting (Fig. 1A). After this recovery period, the fragments were strongly cemented (no corals were dislodged during the transport and outplanting steps) but had not fully skirted tissue onto the ceramic plugs. Due to funding constraints, the parent colonies used in this study were not formally genotyped. Nevertheless, fragments from every parent colony were represented in each reef and treatment and, thus, the results combine the survivorship of corals from three parent colonies per species in experiment one and five parent colonies in experiment two.

\section{Outplanting Experiment One: Assessing Outplant Survivorship}

The first outplanting experiment consisted of four coral species with massive or brain colony morphologies: $O$. faveolata (listed as threatened under the US Endangered Species Act), P. clivosa, P. strigosa, and M. cavernosa. Fragmented corals were glued onto ceramic plugs using polyurethane waterproof glue (Gorilla Glue) (Fig. 1A, B). The plugs with the corals were then mounted into cement pucks with 2-part epoxy putty (AllFix). Finally, these pucks were secured onto the reef using cement (1 part Portland cement, 0.1 part Silica fume), raising corals 3 $\mathrm{cm}$ above the substrate to limit sediment and algal interactions (Fig. 1C). Only corals with healthy (no discoloration or lesions) tissue were used. Corals were outplanted onto three reef sites in Miami, Florida, in June-July 2018: Reef $1\left(25.70^{\circ} \mathrm{N}, 80.09^{\circ} \mathrm{W}\right.$; depth $\left.=6.0 \mathrm{~m}\right)$, Reef 2 $\left(25.68^{\circ} \mathrm{N}, 80.10^{\circ} \mathrm{W} ; 7.5 \mathrm{~m}\right)$, and Reef $3\left(25.83^{\circ} \mathrm{N}, 80.11^{\circ} \mathrm{W} ; 6.4 \mathrm{~m}\right)$. These reefs have low topography and very low cover of stony corals $(<1 \%)$. Corals were collected and outplanted 
122

123

124

125

126

127

128

129

130

131

132

133

134

135

136

137

138

139

140

141

142

143

144

145

146

147

148

149

150

151

152

153

154

155

156

157

158

159

160

under Florida's Fish and Wildlife Commission Permit SAL-19-1794-SCRP. Corals were deployed within replicate grids (from $3 \times 3$ to $5 \times 5 \mathrm{~m}$ ) whose areas were determined based on substrate availability. Four such grids were deployed in Reef 1, 7 in Reef 2, and 6 in Reef 3. The corals were spaced 40-60 cm apart within each grid to maintain a consistent density of corals across replicate plots and grids were separated by at least $2 \mathrm{~m}$. The coral outplants were placed at least $20 \mathrm{~cm}$ away from existing stony and soft corals, sponges, and the zoanthid Palythoa. In total, $53 \mathrm{M}$. cavernosa, 123 O. faveolata, $80 \mathrm{P}$. clivosa, and $41 \mathrm{P}$. strigosa were outplanted among the 3 reefs, with all 4 species represented in each plot.

For each outplant in this experiment, we documented presence/absence of the coral fragment (Fig. 1D) and prevalence (i.e., proportion of corals by species with signs of predation) of tissue mortality caused by predation on remaining fragments (e.g., missing polyps, feeding scars) (Fig. 1E, F) at one week, one month, and six months after deployment. The proportion of corals physically removed by fish predators from their outplanting platforms was compared among coral species, reefs, and time since outplanting using a Generalized Linear Model (GLM) following guidance by Warton and Hui (2011). Here, we used a GLM with a binomial distribution and a logit link function to model the probability of outplant removal. The model incorporated species, reef, and monitoring period (time) as fixed variables. Residuals diagnostics plots were used to test model assumptions, and D-squared values, which indicate the amount of deviance accounted for by the models (i.e., analogous to $\mathrm{R}^{2}$ ), were used to evaluate the goodness of fit of the selected models. Tukey post hoc tests were used to evaluate pairwise differences among the levels of the categorical variables in the models (species, reefs, time). All statistical analyses were performed in R v3.5.3 (R Core Team 2017).

\section{Outplanting Experiment Two: Reducing Predation Impacts}

Based on the high level of predation observed during Experiment One, a second study was designed to determine if predation impacts could be minimized through modifications to the outplanting method. This experiment tested the role of the skeletal profile (i.e., the height of the coral fragment) and attachment medium (glue vs cement) on coral removal and predation rates. This experiment used coral fragments (average size $=2.8 \pm 6.5 \mathrm{~cm}^{2}$ (mean $\pm \mathrm{SD}$ )) from five $P$. clivosa colonies. A high level of predation and abundance of fish predators were recorded at Reef 1 in the first experiment, so this location was chosen as the study site for the second experiment.

Compared to fragments with healed, skirting edges, corals with exposed skeletal walls may provide easier access to the coral tissue and encourage growth of endolithic or turf algae that could attract grazing by fish. Hence, we hypothesized that the exposed skeletal profile (height) and the presence/absence of bare skeleton on the sides of a fragment would influence predation patterns (Fig. 2A-B). We further hypothesized that the rate of the physical removal of outplanted fragments would be related to the attachment method. To test this, we developed a triangular cement platform (cement "pizza"; Fig. 2C-D) that used cement (in lieu of glue) to 
161

162

163

164

165

166

167

168

169

170

171

172

173

174

175

176

177

178

179

180

181

182

183

184

185

186

187

188

189

190

191

192

193

194

195

196

197

198

199

200

secure corals and allowed the height of the fragments to be adjusted by varying the amount of cement used. Corals were secured to the cement pizzas as four treatments:

1) "raised exposed", with fragments placed on top of the cement so that vertical walls (devoid of tissue) protruded from the cement treatment (Fig. 2E);

2) "raised covered", with fragments placed on top of the cement so that vertical walls (covered with tissue) protruded from the cement treatment (Fig. 2F);

3) "flushed", with fragments embedded into the cement so that the fragment was level with the cement platform and only the surface of the coral was visible (Fig. 2G);

4) "embedded", with fragments embedded into the cement so that the coral was positioned $1 \mathrm{~cm}$ below the surface of the cement to prevent access by fish (Fig. $2 \mathrm{H})$.

Individual coral fragments were attached in groups of three (triads) onto each cement pizza to foster coral fusion and faster colony development as described in Paget et al. (2018). The pizzas were cemented individually onto the reef pavement within plots $(n=120$ corals placed onto 40 pizzas). Each plot consisted of 10 pizzas $(n=3-4$ pizzas per treatment), with each pizzaspaced 30-50 $\mathrm{cm}$ apart. Plots were separated by $1 \mathrm{~m}$. In addition to using the cement pizzas, coral fragments were mounted onto ceramic plugs using glue and outplanted directly onto the reef (as used in Page et al. 2018) to serve as controls (Fig. 1B, D). All fragments used as controls had healed skeletal walls covered in tissue. Control corals mounted on plugs were grouped as triads with spacing between corals similar to the pizzas, and deployed directly onto the substrate within the same plots as the experimental corals using cement. Each plot received 5 control triads ( $n=20$ triads, 60 corals). All corals were outplanted in August 2019 and coral condition surveys were conducted immediately after deployment and again after one and three weeks to document the presence/absence of coral fragments and evidence of tissue mortality caused by predation. The average percent tissue removal was estimated visually for each coral using $10 \%$ classification bins. Lastly, the proportion of the tissue area covered by sediments for each coral outplant was visually evaluated at one and three weeks using the methods just described. Values for these two metrics were averaged within pizzas/triads and compared among treatments using ANOVA.

\section{Coral Cover, Fish Abundance, and Predation Surveys}

The percent cover of stony corals at the three reefs selected was calculated using the point-count method as described by Lirman et al. (2007). At each reef, three plots (10 $\mathrm{m}$ in diameter) were haphazardly selected in the vicinity of where the coral fragments were deployed. Within each plot, 25 images were haphazardly collected at a distance of $50 \mathrm{~cm}$ from the bottom. The cover of stony coral was calculated using 25 random points overlaid onto each image using the Coral Point Count with Excel extension (CPCe) software (Kohler and Gill 2006). The proportion of random points placed over stony corals was divided by the total number of points $(n=25$ per image) to calculate the proportional cover of corals. Mean percent coral cover was calculated for each plot ( $n=3$ plots per reef) and averaged for each reef. 
201

202

203

204

205

206

207

208

209

210

211

212

213

214

215

216

217

218

219

220

221

222

223

224

225

226

227

228

229

230

231

232

233

234

235

236

237

238

239

240

Fish surveys to compare fish abundance at coral outplant sites were conducted as part of experiment one at each reef site using the Reef Visual Census (RVC) method (Bohnsack and Bannerot 1986). Using this method, the surveyor recorded the abundance of fish taxa from a stationary point at the center of the study site within a cylindrical 15-m diameter survey area, extending from the substrate to the surface of the water column. Each survey was completed in 15 min and all fishes observed were identified to species level. Between May 2018 and February 2019, we completed 13 RVC surveys at Reef 1, 10 surveys at Reef 2, and 14 surveys at Reef 3. During the 10-month monitoring period, all three reefs were surveyed within one month, with Reefs 1 and 3 surveyed opportunistically additional times. All surveys were completed by a single, expert observer. The mean abundance of all corallivorous or predatory fish (Robertson 1970; Randall 1974) was compared among reefs using ANOVA.

In addition to the visual fish surveys conducted during the coral deployment for experiment one, we deployed a video camera immediately after each coral deployment focused on the newly outplanted corals to document the fish species observed interacting with the corals after the divers had left the plot for both experiments. Each video was viewed and a list of species interacting with the outplants was compiled. The duration of these deployments was variable (1-7 hrs) based on the time spent by the divers at the site during deployment and was only intended to compile a list of fish species approaching and/or biting the corals.

\section{Results}

\section{Outplanting Experiment One: Assessing Predation Impacts}

Two types of fish-predation impacts were documented: 1) physical removal of outplanted fragments, and 2) tissue removal from corals that remained attached to outplanting platforms. The probability of outplant removal was explained by coral species, reef, and time as fixed effects (GLM $\chi^{2}$-test, $\left.\mathrm{p}<0.05\right)$ and the model explained $67 \%$ of the deviance (Fig. 3, Table S1, S2). One week after deployment, $8 \%$ of $M$. cavernosa ( $\mathrm{n}=53$ fragments outplanted), $12 \%$ of $O$. faveolata $(\mathrm{n}=123), 23 \%$ of $P$. clivosa $(\mathrm{n}=80)$, and $27 \%$ of $P$. strigosa $(\mathrm{n}=41)$ fragments were physically removed from the outplant platforms by fish (all sites combined) (Fig. 4A). The ranking of the probability of removal for the four species was consistent across reefs and time (Fig. 3). There was a minor, but significant increase in the probability of removal over time (Fig. 3 , Table S2). The majority of removal occurred during the first week, but corals continued to be removed over time, with an additional $1.9 \%$ of $M$. cavernosa, $6.6 \%$ of $O$. faveolata, $7.1 \%$ of $P$. clivosa, and $7.0 \%$ of $P$. strigosa removed between one and six months after deployment (Fig. 4A).

The species with the highest prevalence of fish bites one week after deployment were the two Pseudodiplora species, followed by O. faveolata. M. cavernosa was the only species that did not show any signs of predation on remaining corals after one week (Fig. 4B). Similar to the rate of removal, predation prevalence slowed over time, as only an average of $0.3 \%$ of surviving corals of all four species combined showed fish bites at the one-month survey compared to $9.2 \%$ after the first week. After six months, no signs of predation were observed for surviving $M$. 
241

242

243

244

245

246

247

248

249

250

251

252

253

254

255

256

257

258

259

260

261

262

263

264

265

266

267

268

269

270

271

272

273

274

275

276

277

278

279

280

cavernosa and $P$. strigosa, and $<1 \%$ of colonies of the remaining two species showed evidence of fish bites (Fig. 4B).

Cover of stony corals recorded at the three outplant sites was very low. Mean coral cover was $0.85( \pm 1.0)$ for Reef $1,0.8( \pm 0.4)$ for Reef 2 , and $0.04( \pm 0.07)$ for Reef 3 . The prevalence of fish predation, including complete fragment removal and fish bites, was highest at Reefs 1 and 2, which coincided with the significantly greater abundance of corallivorous fish taxa recorded at these two sites compared to Reef 3 (ANOVA; Tukey-Kramer HSD test; $p=<0.05$ ) (Fig. 4C, D). The average number of fish observed interacting with the coral outplants (i.e., parrotfishes, damselfishes, butterflyfishes, surgeonfishes, triggerfishes) was 2.7 individuals survey ${ }^{-1} \pm 6.0$ (mean \pm SD) at Reef 1, $2.0 \pm 4.7$ at Reef 2, and only $0.8 \pm 2.3$ at Reef 3 (Fig. 4B). Complete coral removal was $17 \%$ at Reef $1,26 \%$ at Reef 2 , and only $7 \%$ at Reef 3 after one week (Fig. 4C). Similarly, signs of fish predation were higher among the remaining corals at Reef 1 (13.7\% corals with evidence of predation) and Reef 2 (13.1\%), while no evidence of fish bites was observed at Reef 3 after one week (Fig. 4C). The fish taxa observed biting coral fragments included butterflyfishes, parrotfishes, and damselfishes (Table S3). Wrasses and surgeonfishes were also observed approaching the coral outplants but not necessarily biting the coral tissue. While no direct evidence of predation by triggerfishes (a known coral predator) was captured, this taxon was seen in the vicinity of outplants in the video collected in experiment two. Grunts, surgeonfish, and wrasses were the most consistently sighted fish across all 3 sites and were recorded during all 37 surveys. Parrotfishes and damselfishes were also regularly observed at all three outplant locations, having been recorded as being present within 34 and 35, respectively, out of the 37 surveys conducted. Chaetodontidae were recorded within 27 of the 37 surveys, and were present during all 13 surveys at Reef 1,8 out of 10 surveys conducted at Reef 2, but only 6 out of 14 surveys completed at Reef 3 . It is important to note that no evidence of fish removing the corals from their outplanting platforms was captured in our video surveys. Nevertheless, the removal by fish was considered the only driver of the missing corals as corals did not detach during transport nor during their time at the nursery where no fish predators are observed (pers. obs.)

In addition to fragment removal and partial tissue mortality caused by predation, complete coral mortality was observed. After one week, $4 \%$ of P. clivosa, 5\% of O. faveolata, $9 \%$ of $M$. cavernosa, and $17 \%$ of $P$. strigosa fragments that remained attached to the outplant platforms showed 100\% tissue mortality (all sites combined). After six months, the cumulative prevalence of complete mortality was $4 \%$ for $P$. clivosa, $16 \%$ for $M$. cavernosa, $27 \%$ for $P$. strigosa, and $41 \%$ for $O$. faveolata fragments. When removal and complete tissue mortality were combined for all corals and sites combined, $26 \%$ of corals died after one week, $30 \%$ of corals died after one month, and $51 \%$ of corals died within six months of outplanting. Overall, $M$. cavernosa suffered $26 \%$ losses (removal $+100 \%$ tissue mortality), followed by P. clivosa (40\%), O. faveolata (62\%), and, finally, by P. strigosa (73\%). While it was not possible to ascertain the cause of mortality (besides that visibly caused by predation) among the coral outplants, no evidence of active stony coral tissue loss disease (SCTLD), which affected the reefs of South 
281 Florida in recent years, was observed on outplanted or wild corals at any of the sites during either 282 experiment.

283

284

285

286

287

288

289

290

291

292

293

294

295

296

297

298

299

300

301

302

303

304

305

306

307

308

309

310

311

312

313

314

315

316

317

318

319

320

\section{Outplanting Experiment Two: Reducing Predation Impacts}

The mode of attachment of outplanted corals influenced removal patterns. After one week, $14 \%$ of the corals fixed to ceramic plugs using glue were removed, while none of the corals outplanted using cement within the pizzas were missing. After three weeks, still none of the corals deployed on pizzas were removed, whereas $54 \%$ of the corals outplanted using plugs were missing. While none of the corals in any of the four cement pizza treatments were removed, fish predation impacts were significantly affected by coral treatment within the cement bases (ANOVA, $\mathrm{p}<0.05$ ) (Fig. 5). No significant influence of plot was documented and data wer thus grouped for all plots. After three weeks, the average percentage of tissue removed by predation was significantly lowest for corals within the "embedded" treatment and highest for corals placed within the "raised exposed" treatment and corals outplanted using plugs (Tukey-Kramer HSD test; $\mathrm{p}<0.05$ ) (Fig. 5). No significant differences were found between corals in the "raised covered" and "flushed" treatments (Fig. 5). Predation impacts were lowest among embedded corals, but only corals within this treatment experienced sediment accumulation on the surface of the colony. For corals within the embedded treatment, the average of the total surface area of the coral outplants covered by sediments was $3.1 \% \pm 2.4$ (mean \pm SD) after one week and $3.8 \% \pm$ 3.5 (mean $\pm \mathrm{SD}$ ) after three weeks. Neither controls outplanted using plugs nor corals within the other three pizza treatments accumulated sediments on the coral surfaces.

\section{Discussion}

The use of fragmented massive corals expands the number of coral species available for reef restoration beyond the initial, decade-long focus on branching corals. Massive corals are key reef-building taxa that have experienced accelerated losses in the past few years due to the stony coral tissue loss disease (SCTLD) epidemic that was first detected in Florida in 2014 (Precht et al. 2016; Walton et al. 2018) and has now been documented in several locations in the Caribbean (Alvarez-Filip et al. 2019). The impacts of SCTLD, added to the historical declines in these taxa, has created a need to move from single-taxa restoration to a community-based approach that includes corals with different life histories and disturbance responses (Lustic et al. 2020). While massive corals can be successfully propagated both in situ and ex situ (Becker and Mueller 2001; Forsman et al. 2015; Page et al. 2018), our study identified a significant bottleneck in restoration success caused by fish predation on newly outplanted fragments. In our study, $8-27 \%$ of fragments from four species (O. faveolata, M. cavernosa, P. clivosa, $P$. strigosa) outplanted onto three reefs in Miami, Florida, US, were removed by fish within one week. A prior study from Florida also documented large predation impacts on M. cavernosa and O. faveolata, with $45 \%$ and $22 \%$ of fragments affected by predation respectively within the first week (Page et al. 2018). With coral cover being so low presently on Florida reefs $(<1 \%$ coral cover on the reefs used in this study), it is likely that fish predation is being concentrated on outplanted corals, posing

Peer) reviewing PDF | (2020:04:47808:2:0:NEW 21 Aug 2020) 
321

322

323

324

325

326

327

328

329

330

331

332

333

334

335

336

337

338

339

340

341

342

343

344

345

346

347

348

349

350

351

352

353

354

355

356

357

358

359

360

concerns for restoration in depleted systems until a critical abundance threshold is reached (Schopmeyer and Lirman 2015). Supporting this concept, Jayewardene et al. (2009) found lower prevalence of fish bites on coral nubbins in plots with higher coral cover. The concentration of predation on surviving corals after major declines in abundance due to a hurricane was previously documented by Knowlton et al. (1990).

Previously, research efforts have focused mainly on the impacts of reef fishes on the abundance and distribution of macroalgae, so our understanding of their direct effects on stony corals is comparatively more limited. Only 10 families of fishes have been reported to consume coral polyps and even fewer taxa classified as obligate corallivores (Robertson 1970; Randall 1974). Species within the Chaetodontidae (butterflyfishes), Balistidae (triggerfishes), and Tetraodontidae (pufferfishes) families are among the most common corallivorous fishes (Hixon 1997). In this study, butterflyfish, wrasses, parrotfish, surgeonfish, and damselfish consumed or interacted with newly outplanted corals. Except for butterflyfishes that were observed biting coral tissue, it remained unclear from our visual and video observations whether fragments were physically removed by fish grazing on algae growing on exposed coral skeletons or direct consumption of coral tissue.

The high impacts recorded here on coral outplants may be the result of consumptive or territorial activity (or a combination of both). Both butterflyfishes (Reese 1989; Roberts and Ormand 1992) and the adult terminal phase male stoplight parrotfish Sparisoma viride (Bruggemann et al. 1994; Bruckner et al. 2000) have been observed to bite corals within their territories, which supports that certain fish species may selectively target new coral outplants as soon as they appear within their territories. Predation impacts on coral outplants were highest within the first week and tapered off with time, declining to $<1 \%$ of remaining corals removed after six months, suggesting outplant habituation of the fish fauna to new coral "recruits" may play a role. Similar patterns of temporal predation on coral outplants were reported in Guam, where predation impacts from butterflyfishes and triggerfishes were high within one week of deployment (Neudecker 1979). Whether the decline in coral removal by fish was a result of corals reaching a size refuge as they grew or due to habituation of the fish to the presence of these corals could not be ascertained in this study. The territories of potential fish predators like parrotfishes were not assessed in this study and we were thus unable to differentiate between the impacts of both these factors nor their interaction. Similarly, the high level of predation may have been caused by the relatively close spacing of outplanted corals $(30-60 \mathrm{~cm})$ so that once a prey item was detected, detection of additional corals within a grid was autocorrelated. Thus, the potential role of fish territoriality and spacing of corals on impacts on newly outplanted corals needs further investigation, especially considering the high impacts recorded here that represent a drain in restoration resources.

In our study, impacts of predation varied by species, with $P$. clivosa and P. strigosa experiencing the highest levels of mortality. While the potential reasons for the differences in species susceptibility to predation were not measured here, factors such as palatability, nutritional content, or skeletal characteristics may play a role and need to be investigated further. 
361 Nevertheless, prey selection based on coral species has been previously documented for 362 Chaetodon unimaculatus that showed a preference for feeding on Montipora verrucosa in 363 Hawaii (Cox 1986), by Balistapus undulatus that targeted Pocillopora damicornis over 364 Seriatopora hystrix (Gibbs and Hay 2015), and by butterflyfish that target Acropora over other 365 coral taxa (Berumen 2005). Similarly, wild and outplanted A. cervicornis and O. annularis were 366 targeted by the territorial three-spot damselfish (Kaufman 1977; Knowlton et al. 1990; 367 Schopmeyer and Lirman 2015).

368 Fish predation impacts varied by reef and were associated with the abundance of fish taxa 369 known to consume coral tissue. Differences in predation impacts on outplanted coral fragments 370 between sites were also documented by Paige et al. (2018) in the Florida Keys. Similar to our 371 findings, Quimpo et al. (2019) suggested that coral outplants were more likely to be detached 372 when outplanted onto reefs with higher biomass of herbivore and corallivore fishes in the 373 Phillipines. Additionally, Quimpo et al. (2019) reported that incidental grazing of herbivorous 374 fish, particularly the parrotfish Chlorurus spilurus, were the main sources of coral detachment, 375 but that the direct predation by corallivorous fishes only minimally affected coral outplants. 376 Incidental fish predation was also observed by herbivorous fish removing algal tissue from 377 nursery ropes in the Seychelles by Frias-Torres and van de Geer (2015). A simple response to

378

379

380

381

382

383

384

385

386

387

388

389

390

391

392

393

394

395

396

397

398

399 these patterns would be to avoid outplanting on reefs with high abundance of these taxa, but it is important to note that parrotfishes and surgeonfishes (observed here to target outplanted corals) are also key grazers that are essential to maintain a low abundance of macroalgae on reefs (Mumby et al. 2006) and coral nursery settings (Knoester et al. 2019). Best practices for the selection of outplanting sites developed for Acropora suggest that low abundance of macroalgae is a key attribute of an ideal restoration site (Johnson et al. 2011). In addition to reducing algal overgrowth, damselfish, triggerfishes, puffers, and other corallivorous fish have been documented to limit impacts of corallivorous invertebrates such as the crown-of-thorns starfish (Acanthaster plancii) and Coralliophillia snails (Ormond et al. 1973; Schopmeyer and Lirman 2015). Hence, avoiding reefs with a high abundance of grazers that also target corals is not a viable option as it may lead to algal overgrowth and higher impacts by non-fish corallivores. There is, thus, a clear need to develop efficient outplanting methods to minimize the impacts of fish predation on reefs with high abundances of fish herbivores.

While fish impacts were the predominant source of physical removal of fragments in the present study, remaining corals experienced tissue losses due to fish predation and other unknown factors resulting in the mortality of $>30 \%$ of remaining corals after six months. Fish predation has also been shown to reduce growth rates (Meesters et al. 1994), decrease fecundity (Szmant-Froelich 1985; Rinkevich and Loya 1989), and increase susceptibility to diseases (Williams and Miller 2005; Aeby and Santavy 2006). Mortality of our outplanted corals was much higher than the average mortality (14.8\%) reported for A. cervicornis one year after outplanting (Schopmeyer et al. 2017), highlighting a bottleneck that needs to be addressed to optimize the long-term success of using fragmented massive corals for restoration. 
400

401

402

403

404

405

406

407

408

409

410

411

412

413

414

415

416

417

418

419

420

421

422

423

424

425

426

427

428

429

430

431

432

433

434

435

436

437

438

439

440

441

Lower fragment removal rates and reduced prevalence of fish predation were related to the attachment method (glue vs. cement). None of the fragments attached by cement were removed by fish predators showing that cement provides a stronger hold for the outplanted corals than the commonly used glue. Higher detachment of coral fragments attached with glue was also documented by Dizon et al. (2008). Moreover, corals allowed to recover tissue over their exposed skeletal walls prior to outplanting ("raised healed" treatment) had less predation than corals with exposed skeletal walls ("raised exposed" treatment). Colony edges of exposed skeleton can be preferentially targeted by parrotfish feeding on turf or endolithic algae, resulting in the higher prevalence of fish bites recorded (Bruckner and Bruckner 1998). Thus, allowing fragmented corals to skirt over the exposed skeleton and grow onto the attachment platform would be the desired step before outplanting. This approach is used in the microfragmentation method described by Page et al. (2018) where small microfragments composed mainly of tissue with limited skeleton are grown ex situ until the coral tissue reaches the edges of the ceramic plug, resulting in larger coral outplants without exposed skeletal walls and low height, thereby reducing predation risk. This would increase the time a fragment remains within nurseries but would also limit predation impacts. Finally, embedding corals into the cement platform ("embedded treatment") mimics this process by lowering coral height and the amount of skeletal walls exposed and reduced predation prevalence to $<1 \%$ of corals. While placing corals embedded into cement may be an option for limiting removal and predation mortality, embedded corals had $>3 \%$ of the coral tissue covered by sediments, highlighting a potential tradeoff between reduced predation and sediment impacts that needs to be further evaluated.

Lastly, one of the factors that may have resulted in the high levels of removal and predation recorded here may have been the size of the coral fragments used in this study. Prior research has shown a relationship between the size of the fragments or colonies used for restoration and their survivorship and susceptibility to fish predation. For example, a size refuge for coral nubbins was documented by Christiansen et al. (2009), Jayewardene et al. (2009), Gibbs and Hay (2015), and Quimpo et al. (2019) in field or laboratory experiments. Moreover, in a recent study by Lustic et al. (2020), medium-sized $\left(40-130 \mathrm{~cm}^{2}\right)$ colonies of Orbicella faveolata and Montastraea cavernosa outplanted onto a reef in the Florida Keys showed no significant impacts of fish predation, highlighting a potential size threshold for predationimpacts. Thus, the impacts from fish predation may be mitigated in Florida by outplanting larger fragments or, as described by Page et al. (2018), by deploying smaller corals together as tight clusters to foster fusion and function as a larger skeletal unit. There is a trade-off between the number of corals derived from a single parent and the size of the fragments produced, so controlled experiments on the role of size on predation susceptibility are needed before the optimum size of massive coral outplants can be established, especially in habitats with high levels of fish predation.

\section{Conclusions}

As coral declines continue worldwide, active reef restoration has emerged as a powerful management alternative to slow down and eventually help reverse these declines (Natl. Acad. 
442 Sci. 2019). As the number of techniques and species used in restoration increase beyond the 443 established success of branching corals, practitioners and scientists are collaborating to develop 444 expanded guidelines and best practices. These are critically needed to both broaden the footprint 445 of restoration while keeping restoration costs down. Our study, based on the restoration of small 446 fragments $\left(<5 \mathrm{~cm}^{2}\right)$ of four species of massive corals, identified predation by fish as a major 447 bottleneck in restoration success as the activities of a subset of fish taxa (butterflyfishes, wrasses,

448

449

450

451

452

453

454

455

456

457

458

459

460

461

462

463

464

465

466

467

468

469

470

471

472

473

474

475

476

477

478

479

480

481 parrotfishes, surgeonfishes, damselfishes) caused both the high rates of removal of fragments and tissue mortality on remaining fragments. Thus, there is a need to develop methods to reduce these predatory impacts for massive-coral fragments for restoration to be an effective tool in Florida. Here, we identified fragment attachment method (cement performed better than glue) and coral placement (fragments performed better with tissue covering the skeletal walls, and deployed either flushed or embedded within outplanting platforms) as factors that can be used to reduce impacts. We also identified the need to conduct additional experiments to discern the interactive role of fish abundance and territoriality on fragment performance and to explore the role of fragment size and species palatability on survivorship. We believe that the recent development and adoption of microfragmentation as a technique for massive coral propagation will provide the corals needed to develop more efficient outplanting methods and circumvent the fish predation bottleneck identified here in the near future, allowing for the successful restoration of these keystone species.

\section{Acknowledgements}

We would like to thank S. Schopmeyer, M. Kaufman, J. Carrick, J. Unsworth, and R. Delp for their help in the field. This project was funded by a grant from NOAA's Restoration Center (award OAA-NMFS-HCPO-2016-2004840). We appreciate the input by PeerJ editors, Dr. E. Muller, and two anonymous reviewers.

\section{References}

Aeby GS, Santavy DL (2006) Factors affecting susceptibility of the coral Montastraea faveolata to black-band disease. Mar Ecol Prog Ser 318:103-110

Alvarez-Filip L, Estrada-Saldívar N, Pérez-Cervantes E, Molina-Hernández A, González-Barrios FJ (2019) A rapid spread of the stony coral tissue loss disease outbreak in the Mexican Caribbean. PeerJ 7:e8069 DOI 10.7717/peerj.8069

Becker LC, Mueller E (2001) The culture, transplantation and storage of Montastraea faveolata, Acropora cervicornis and Acropora palmata: what we have learned so far. Bull Mar Sci 69:881-896

Berumen ML, Pratchett MS, McCormick MI (2005) Within-reef differences in diet and body condition of coral-feeding butterflyfishes (Chaetodontidae). Mar Ecol Prog Ser 287:217227

Bohnsack JA, Bannerot SP (1986) A stationary visual census technique for quantitatively assessing community structure of coral reef fishes. NOAA Technical Report NMFS 41 
482

483

484

485

486

487

488

489

490

491

492

493

494

495

496

497

498

499

500

501

502

503

504

505

506

507

508

509

510

511

512

513

514

515

516

517

518

519

520

Bowden-Kerby A (2008) Restoration of threatened Acropora cervicornis corals: intraspecific variation as a factor in mortality, growth, and self-attachment. Proc 11th Int Coral Reef Symp 2:1200-1204

Brandl SJ, Tornabene L, Goatley CH, Casey JM, Morais RA, Côté IM, Baldwin CC, Parravicini V, Schiettekatte NM, Bellwood DR (2019) Demographic dynamics of the smallest marine vertebrates fuel coral reef ecosystem functioning. Science 364:1189-1192

Bruckner AW, Bruckner RJ (1998) Destruction of coral by Sparisoma viride. Coral Reefs 17:350

Bruckner AW, Bruckner RJ, Sollins P (2000) Parrotfish predation on live coral: "spot biting" and "focused biting". Coral Reefs 19:50-50

Bruggemann JH, Kuyper MWM, Breeman AM (1994) Comparative analysis of foraging and habitat use by the sympatric Caribbean parrotfish Scorus and Sparisonia iiirirle (Scaridae). Mar Ecol Prog Ser 112:51-66

Cox EF (1986) The effects of a selective corallivore on growth rates and competition for space between two species of Hawaiian corals. J Exp Mar Bio Ecol 101:161-174

Christiansen NA, Ward S, Harii S, Tibbetts IR (2009) Grazing by a small fish affects the early stages of a post-settlement stony coral. Coral Reefs 28:47-51

Cunning R, Silverstein RN, Barnes BB, Baker AC (2019) Extensive coral mortality and critical habitat loss following dredging and their association with remotely-sensed sediment plumes. Mar Pollut Bull 145:185-199

Drury C, Schopmeyer S, Goergen E, Bartels E, Nedimyer K, Johnson M, Maxwell K, Galvan V, Manfrino C, Lirman D (2017) Genomic patterns in Acropora cervicornis show extensive population structure and variable genetic diversity. Ecol Evol 7:6188-6200

Dizon RM, Edwards AJ, Gomez ED (2008) Comparison of three types of adhesives in attaching coral transplants to clam shell substrates. Aquat Conserv 18:1140-1148

Forsman ZH, Page CA, Toonen RJ, Vaughan D (2015) Growing coral larger and faster: microcolony-fusion as a strategy for accelerating coral cover. PeerJ 3:e1313

Frias-Torres S, van de Geer C (2015) Testing animal-assisted cleaning prior to transplantation in coral reef restoration. PeerJ 3:e1287

Gardner TA, Côté IM, Gill JA, Grant A, Watkinson AR (2003) Long-term region-wide declines in Caribbean corals. Science 301:958-960

Gibbs DA, Hay ME (2015) Spatial patterns of coral survivorship: impacts of adult proximity versus other drivers of localized mortality. PeerJ 3:e1440

Heron SF, Maynard JA, Van Hooidonk R, Eakin CM (2016) Warming trends and bleaching stress of the world's coral reefs 1985-2012. Sci Rep 6:38402

Hixon MA (1997) Effects of reef fishes on corals and algae. In Life and Death of Coral Reefs, C. Birkeland (ed.). New York: Chapman and Hall, pp 230-246

Hoey AS, Howells E, Johansen JL, Hobbs J-PA, Messmer V, McCowan DM, Wilson SK, Pratchett MS (2016) Recent advances in understanding the effects of climate change on coral reefs. Diversity 8:12

Peer) reviewing PDF | (2020:04:47808:2:0:NEW 21 Aug 2020) 
521 Hughes TP, Kerry JT, Baird AH, Connolly SR, Chase TJ, Dietzel A, Hill T, Hoey AS,

522

523

524

525

526

527

528

529

530

531

532

533

534

535

536

537

538

539

540

541

542

543

544

545

546

547

548

549

550

551

552

553

554

555

556

557

558

559

560

Hoogenboom MO, Jacobson M, Kerswell A (2019) Global warming impairs stockrecruitment dynamics of corals. Nature 568:387

Jayewardene D, Donahue MJ, Birkeland C (2009) Effects of frequent fish predation on corals in Hawaii. Coral Reefs 28:499-506

Johnson ME, Lustic C, Bartels E, Baums IB, Gilliam DS, Larson L, Lirman D, Miller MW, Nedimyer K, Schopmeyer S (2011) Caribbean Acropora restoration guide: best practices for propagation and population enhancement. The Nature Conservancy, Arlington, VA.

Kaufman L (1977) The three-spot damselfish: effects on benthic biota of Caribbean coral reefs. Proc 3rd Int Coral Reef Symp 1:559-564

Knoester EG, Murk AJ, Osinga R (2019) Benefits of herbivorous fish outweigh costs of corallivory in coral nurseries placed close to a Kenyan patch reef. Mar Ecol Prog Ser 611:143-155

Knowlton N, Lang JC, Keller BD (1990) Case study of natural population collapse: posthurricane predation on Jamaican staghorn corals. Smithsonian Contributions to the Marine Sciences 31:1-22

Kohler KE, Gill SM (2006) Coral Point Count with Excel extensions (CPCe): A Visual Basic program for the determination of coral and substrate coverage using random point count methodology. Comput Geosci 32:1259-1269

Lapointe BE, Brewton RA, Herren LW, Porter JW, Hu C (2019) Nitrogen enrichment, altered stoichiometry, and coral reef decline at Looe Key, Florida Keys, USA: a 3-decade study. Mar Biol 166:108

Lirman D, Fong P (1997) Patterns of damage to the branching coral Acropora palmata following Hurricane Andrew: damage and survivorship of hurricane-generated asexual recruits. J Coast Res 67-72

Lirman D, Schopmeyer S, Galvan V, Drury C, Baker AC, Baums IB (2014) Growth dynamics of the threatened Caribbean staghorn coral Acropora cervicornis: influence of host genotype, symbiont identity, colony size, and environmental setting. PloS one 9:e107253

Lirman D, Gracias NR, Gintert BE, Gleason ACR, Reid RP, Negahdaripour S, Kramer P (2007) Development and application of a video-mosaic survey technology to document the status of coral reef communities. Environ Monitor Assess 125:59-73

Lirman D, Thyberg T, Herlan J, Hill C, Young-Lahiff C, Schopmeyer S, Huntington B, Santos R Drury C (2010) Propagation of the threatened staghorn coral Acropora cervicornis: methods to minimize the impacts of fragment collection and maximize production. Coral Reefs 29:729-735

Lustic C, Maxwell K, Bartels E, Reckenbeil B, Utset E, Schopmeyer S, Zink I, Lirman D (2020) The impacts of competitive interactions on coral colonies after transplantation: A multispecies experiment from the Florida Keys, US. Bull Mar Sci. https://doi.org/10.5343/bms.2019.0086

Manzello DP (2015) Rapid recent warming of coral reefs in the Florida Keys. Sci Rep 5:16762

Peer) reviewing PDF | (2020:04:47808:2:0:NEW 21 Aug 2020) 
561

562

563

564

565

566

567

568

569

570

571

572

573

574

575

576

577

578

579

580

581

582

583

584

585

586

587

588

589

590

591

592

593

594

595

596

597

598

599

600

McLean M, Cuetos-Bueno J, Nedlic O, Luckymiss M, Houk P (2016) Local stressors, resilience, and shifting baselines on coral reefs. PloS one 11:e0166319

Meesters EH, Noordeloos M, Bak RP (1994) Damage and regeneration: links to growth in the reef-building coral Montastrea annularis. Mar Ecol Prog Ser 112:119-128.

Muehllehner N, Langdon C, Venti A, Kadko D (2016) Dynamics of carbonate chemistry, production, and calcification of the Florida Reef Tract (2009-2010): Evidence for seasonal dissolution. Global Biogeochem Cycles 30:661-688

Mumby PJ, Dahlgren CP, Harborne AR, Kappel CV, Micheli F, Brumbaugh DR, Holmes KE, Mendes JM, Broad K, Sanchirico JN, Buch K (2006) Fishing, trophic cascades, and the process of grazing on coral reefs. Science 311:98-101National Academies of Sciences, Engineering, and Medicine. 2019. A Research Review of Interventions to Increase the Persistence and Resilience of Coral Reefs. Washington, DC: The National Academies Press. https://doi.org/10.17226/25279

Nedimyer K, Gaines K, Roach S (2011) Coral Tree NurseryC: An innovative approach to growing corals in an ocean-based field nursery. Aquac Aquar Conserv Legis 4:442-446

Neudecker S (1979) Effect of grazing and browsing fishes on the zonation of corals in Guam. Ecology 60:666-672

Ormond RFG, Campbell AC, Head SH, Moore RJ, Rainbow PR, Saunders AP (1973) Formation and breakdown of aggregations of the crown-of-thorns starfish, Acanthaster planci (L.). Nature 246:167

Page CA, Muller EM, Vaughan DE (2018) Microfragmenting for the successful restoration of slow growing massive corals. Ecol Eng 123:86-94

Precht WF, Gintert BE, Robbart ML, Fura R, Van Woesik R (2016) Unprecedented diseaserelated coral mortality in Southeastern Florida. Sci Rep 6:31374

Quimpo TJR, Cabaitan, Hoey, AS (2019) Detachment of Porites cylindrical nubbins by herbivorous fishes. Restor Ecol. https://doi:10.1111/rec.13091

Randall JE (1974) The effect of fishes on coral reefs. Proc 2nd Int Coral Reef Symp 1:59-166

R Core Team (2017) R: A Language and Environment for Statistical Computing. https://www.R-project.org/

Reese ES (1977) Coevolution of corals and coral feeding fishes of the family Chaetodontidae. Proc 3rd Int Coral Reef Symp 1:267-274

Reese ES (1989) Orientation behavior of butterflyfishes (family Chaetodontidae) on coral reefs: spatial learning of route specific landmarks and cognitive maps. Environ Biol Fishes 25:79-86

Richardson LL, Goldberg WM, Carlton RG, Halas JC (1998) Coral disease outbreak in the Florida Keys: Plague Type II. Rev. Biol. Trop. 46:187-198

Rinkevich B (2006) The coral gardening concept and the use of underwater nurseries: lessons learned from silvics and silviculture. Coral reef restoration handbook pp 291-302

Rinkevich B (2019) The active reef restoration toolbox is a vehicle for coral resilience and adaptation in a changing world. J Mar Sci Eng 7:201 
601 Rinkevich B, Loya Y (1989) Reproduction in regenerating colonies of the coral Stylophora

602

603

604

605

606

607

608

609

610

611

612

613

614

615

616

617

618

619

620

621

622

623

624

625

626 pistillata. Environmental quality and ecosystem stability 4:257-265

Roberts CM, Ormond RF (1992) Butterflyfish social behaviour, with special reference to the incidence of territoriality: a review. Environ Biol Fishes 34:79-93

Robertson R (1970) Review of the predators and parasites of stony corals, with special reference to symbiotic prosobranch gastropods. Pacific Science 24:43-54

Rotjan RD, Lewis SM (2006) Parrotfish abundance and selective corallivory on a Belizean coral reef. J Exp Mar Bio Ecol 335: 292-301

Rotjan RD, Lewis SM (2008) Impact of coral predators on tropical reefs. Mar Ecol Prog Ser 367:73-91

Schopmeyer SA, Lirman D (2015) Occupation dynamics and impacts of damselfish territoriality on recovering populations of the threatened staghorn coral, Acropora cervicornis. PLoS One 10:e141302

Schopmeyer SA, Lirman D, Bartels E, Gilliam DS, Goergen EA, Griffin SP, Johnson ME, Lustic C, Maxwell K, Walter CS (2017) Regional restoration benchmarks for Acropora cervicornis. Coral Reefs 36:1047-1057

Shaish L, Levy G, Katzir G, Rinkevich B (2010) Employing a highly fragmented, weedy coral species in reef restoration. Ecol Eng 36:1424-1432

Szmant-Froelich A (1985) The effect of colony size on the reproductive ability of the Caribbean coral Montastrea annularis (Ellis and Solander). Proc 5th Int Coral Reef Symp 4:295-300

Walton C, Hayes NK, Gilliam DS (2018) Impacts of a regional, multi-year, multi-species coral disease outbreak in Southeast Florida. Front Mar Sci 5:323

Warton DI, Hui FKC (2011) The arcsine is asinine: the analysis of proportions in ecology. Ecology 92:3-10

Williams DE, Miller MW (2005) Coral disease outbreak: pattern, prevalence and transmission in Acropora cervicornis. Mar Ecol Prog Ser 301:119-128 


\section{Figure 1}

Corals outplanted using methods from experiment 1 and examples of fish predation.

A) coral fragments deployed at the UM nursery for recovery prior to outplanting, B)

Pseudodiploria clivosa fragment outplanted using a ceramic plug, C) Orbicella faveolata fragment outplanted using a cement puck, D) triad of coral fragments outplanted using ceramic plugs showing the complete removal of the coral on the top of the image by fish, E-

F) evidence of fish predation on outplanted fragments as shown by the white skeletal lesions without living tissue.
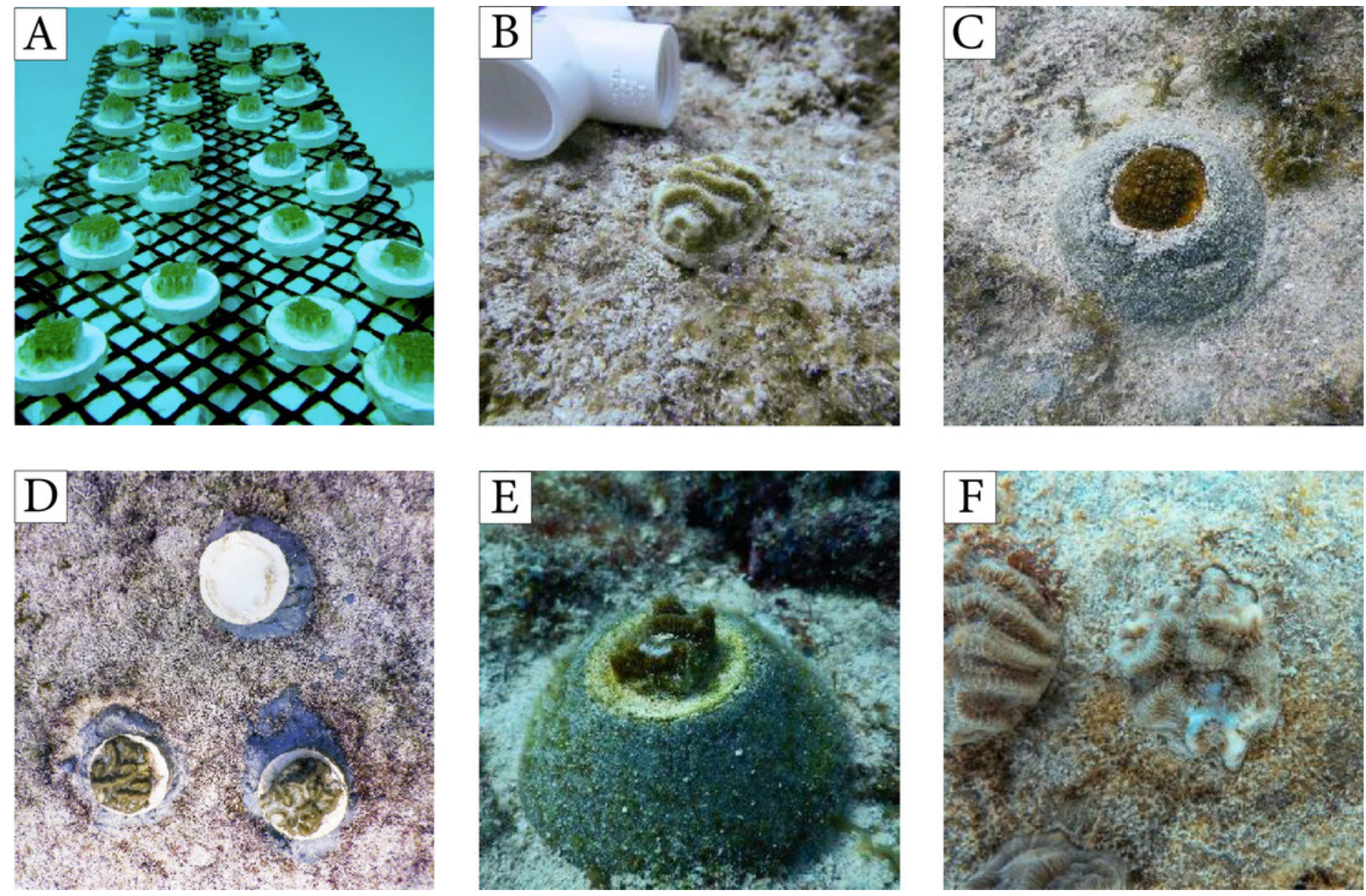


\section{Figure 2}

Corals ouplanted using methods from experiment 2.

A) coral fragments showing exposed skeletal walls, B) coral fragment with tissue-covered walls, C) corals outplanted using a cement pizza, D) individual ceramic plugs, E) fragments with exposed walls on a cement pizza, F) fragments with covered walls on a cement pizza, G) fragments placed flushed within a cement pizza, H) fragments embedded into a cement pizza.
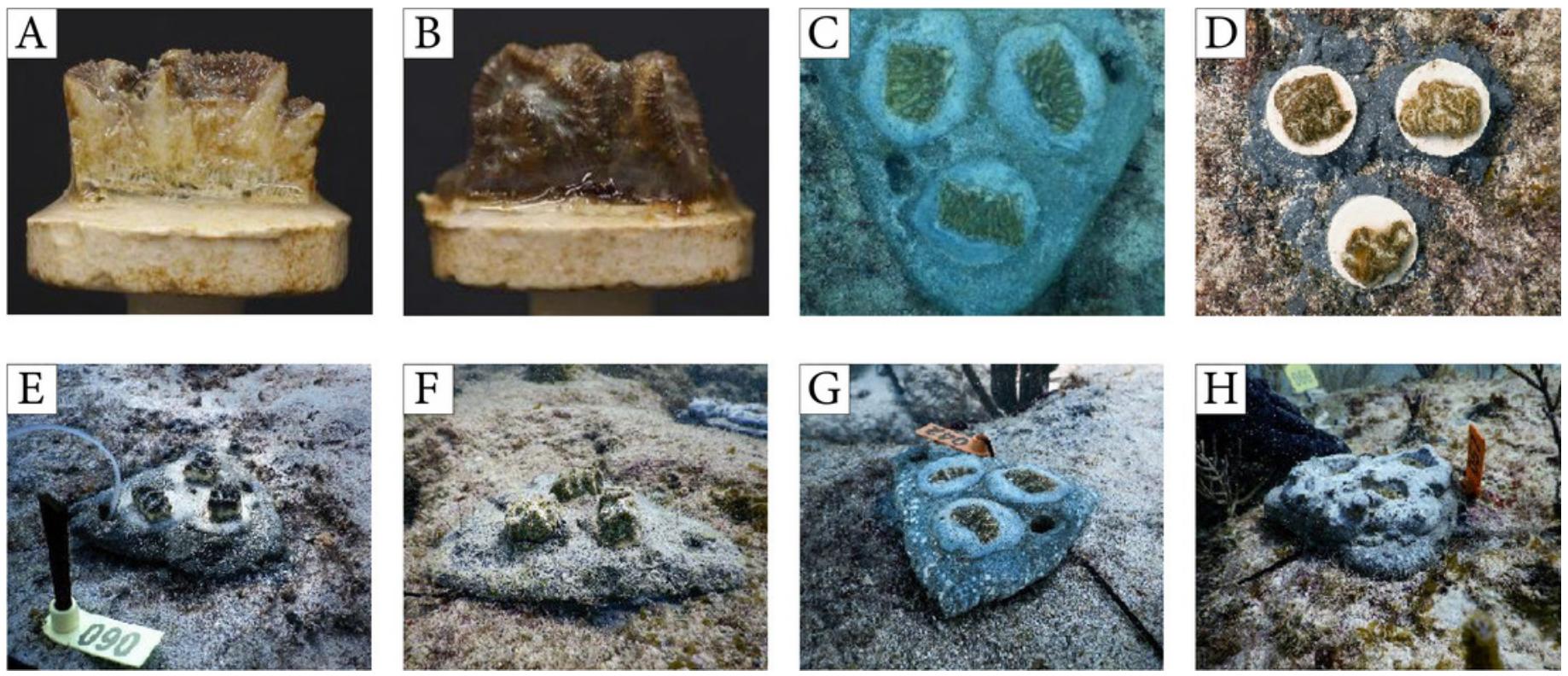
Figure 3

Probability of coral removal by fish based on species, reefs, and time since outplanting estimated using a binomial GLM.

Bars indicate the GLM fitted values (center lines) and 95 percent confidence intervals (upper/lower extension of the box). According to Tukey pairwise tests: Mcav $=$ Ofav $\neq$ Pcliv $=$ Pstri; Reef $1=$ Reef 2, Reef $1 \neq$ Reef 3, Reef $2 \neq$ Reef 3. Mcav = Montastraea cavernosa, Ofav $=$ Orbicella faveolata, Pcliv $=$ Pseudodiploria clivosa, Pstri $=$ Pseudodiploria strigosa .

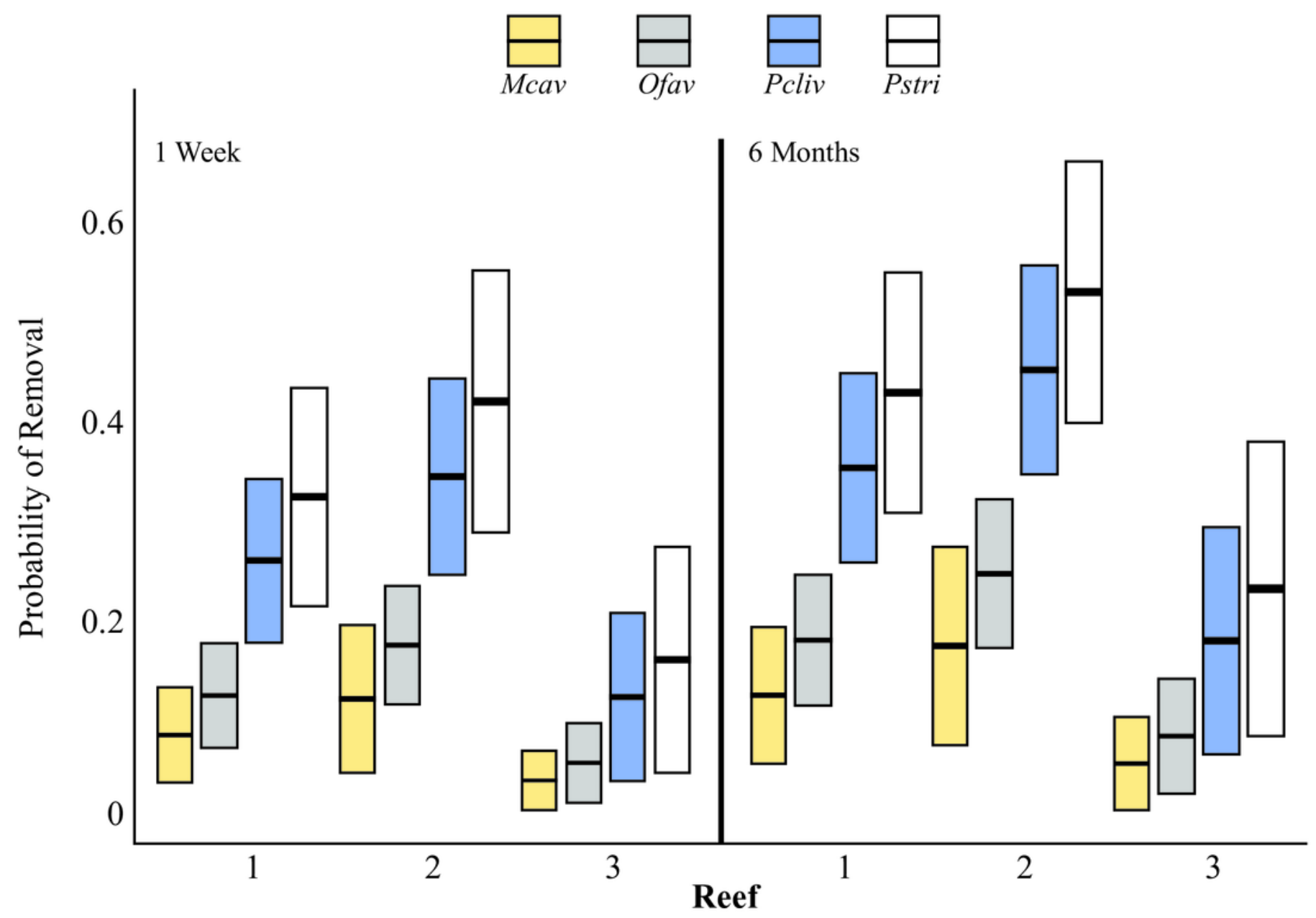




\section{Figure 4}

Impacts of fish predation on coral outplants.

A) Average cumulative ( \pm S.D.) percent of corals removed by species at the different survey time points for all reefs combined in experiment 1, B) Average ( \pm S.D.) percent of remaining corals by species showing signs of predation for all reefs combined, C) Cumulative percent of outplanted corals removed (left) and percent of coral remaining showing signs of predation (right) for all species combined, D) Average ( \pm S.D.) abundance of fish taxa that interacted with outplanted corals at the outplanting reefs based on the RVC fish surveys conducted at all 3 reefs. Mcav $=$ Montastraea cavernosa, Ofav $=$ Orbicella faveolata, Pcliv $=$ Pseudodiploria clivosa, Pstri $=$ Pseudodiploria strigosa.
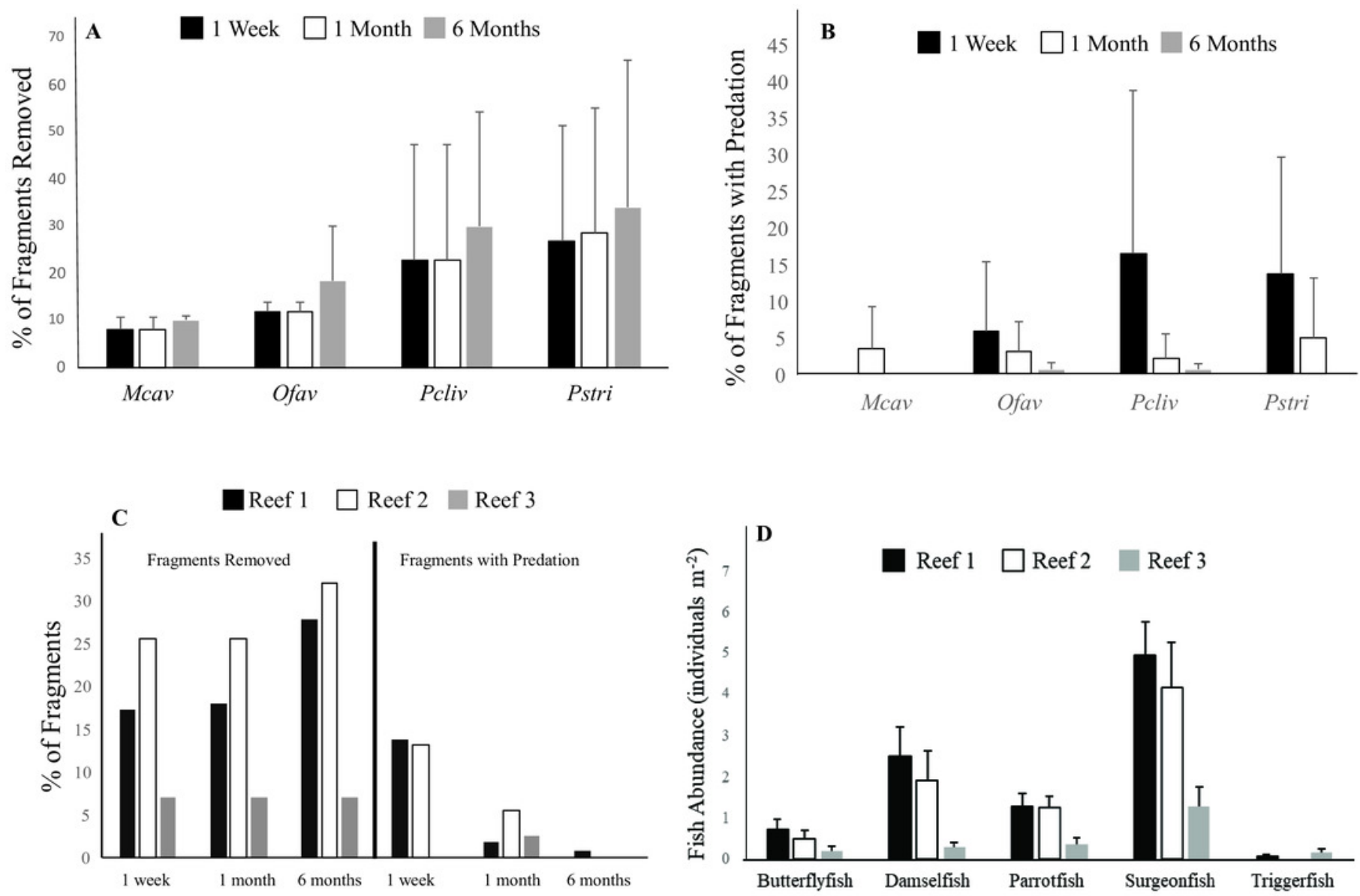
Figure 5

Average percent tissue ( \pm S.D.) surface area removed from Pseudodiploria clivosa outplants based on outplanting method after 3 weeks.

Black bars show fragments outplanted using cement pizzas ( $n=10$ pizzas per treatment), grey bar shows corals glued onto ceramic plugs ( $n=14$ triads). Capital letters indicate assignment into significant groupings based on a Tukey-Kramer HSD test $(p<0.05)$.

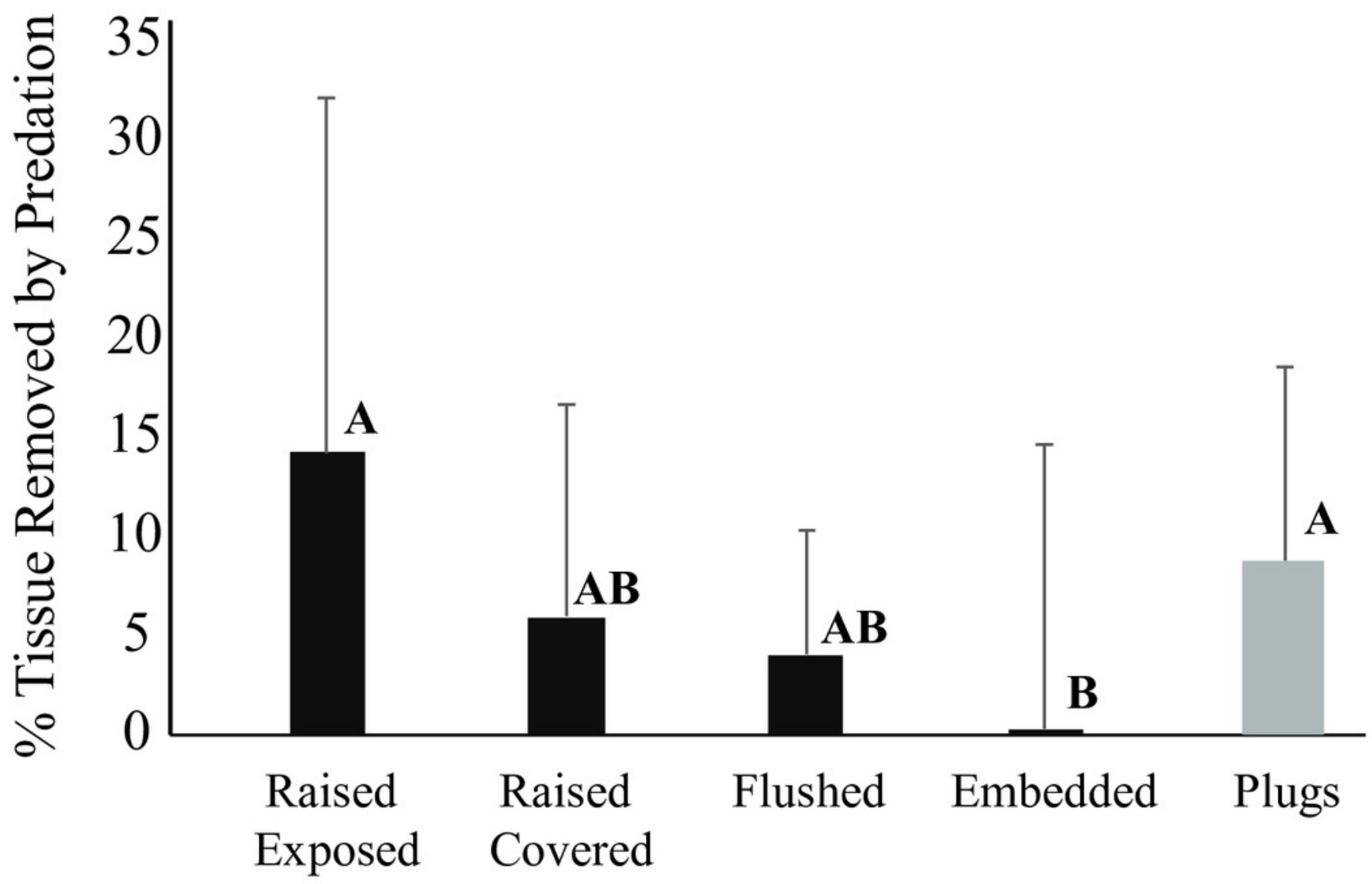

